\title{
Updating Political Evaluations: Policy Attitudes, Partisanship, and Presidential Assessments
}

\author{
Benjamin Highton
}

Published online: 16 February 2011

(C) The Author(s) 2011. This article is published with open access at Springerlink.com

\begin{abstract}
The pervasive influence of partisanship on political evaluations is well known and understood. Whether citizens rely on their policy attitudes has received less attention, especially in the context of how people update and revise their evaluations. This paper focuses on presidential assessments and uses panel data covering three presidencies to model the determinants of opinion change. The results indicate that policy preferences (like partisanship) exert a regular and substantial influence on how citizens update their presidential evaluations.
\end{abstract}

Keywords Issues $\cdot$ Policy preferences $\cdot$ Presidential approval $\cdot$ Partisanship $\cdot$ Party identification · Updating

In politics, citizens rarely act immediately upon forming their opinions about candidates for elective office. Political campaigns extend over time, offering ample opportunities for people to update and revise their opinions. Candidates, once elected, typically serve over a period of years before facing the electorate to seek reelection. Thus how people update and revise their evaluations of elected officials is important for understanding the nature of democratic accountability.

This paper focuses on the process by which ordinary citizens update their presidential assessments. Most previous research on presidential evaluations focuses on either the dynamics of aggregate presidential approval or cross-sectional

I appreciate advice and criticism from Cindy Kam, Laura Stoker, Nick Valentino, the participants in the Institute of Governmental Studies Research Workshop on American Politics at UC Berkeley, and the reviewers and editors for Political Behavior.

B. Highton ( $\square)$

Department of Political Science, University of California, One Shields Avenue, Davis, CA 95616-8682, USA

e-mail: bhighton@ucdavis.edu 
differences at a single point in time. ${ }^{1}$ Analyses of change in individual evaluations are rare. Rarer still are examinations of individual change that focus on policy attitudes. While there appears to be a regular and substantial influence of partisanship (Bartels 2002), the extent to which people routinely rely on their policy attitudes as day-to-day political events unfold is unknown. As a result, many questions about the nature of public opinion, how people process and respond to new information, and the role of individual attitudes for moderating how public opinion develops over time remain unanswered. ${ }^{2}$

Determining if policy attitudes shape how people update their presidential evaluations is important for theoretical and normative reasons. Theoretically, there are key connections to questions about information exposure and processing raised by political psychologists. The early Columbia studies established that through their decisions and social networks people are selectively exposed to political information that is likely to accord with their partisan inclinations (Lazarsfeld et al. 1948; Berelson et al. 1954). Recent research focuses on "motivated reasoning" to explain how people process the information to which they are exposed and identifies a variety of mechanisms by which people may arrive at different assessments even when exposed to identical information (Lodge and Taber 2000). The work on motivated reasoning provides the causal underpinning for the famous observation by Stokes (1966) about the "subtle processes of perceptual adjustment by which the individual assembles an image of current politics consistent with his partisan allegiance" (p. 127). In relation to the president, citizens may be motivated to maintain evaluations consistent with their partisanship. However, because presidents also take positions on policy, the theory of motivated reasoning may also be important for understanding the role of policy attitudes in the process of updating.

Assessing how people revise their political evaluations in light of their policy and partisan attitudes also relates to important normative questions. Democratic theory often presumes that ordinary citizens base their evaluations of political leaders on how closely their preferences match the positions endorsed and opposed by leaders. If this condition holds, then mass support for the president provides justification for the president's policy agenda. But, Converse warns that "it is difficult to keep in mind that the true motivations and comprehensions of supporters may have little or nothing to do with the distinctive beliefs of the endorsed elite (Converse 1964, p. 249, emphasis added). If people respond primarily in partisan terms, then "party bias" is pervasive, pushing aside more "rational" and "democratic" updating in response to policy attitudes. However the different types of updating are labeled, the meaning of changes in public opinion depends on the relative contributions of partisanship and policy attitudes even if the same general process-motivated reasoning-underlies both because "in [democratic] theory of course the party

\footnotetext{
${ }^{1}$ Gronke and Newman (2003) provide an excellent synthesis of the research on presidential evaluations.

2 This paper addresses the understudied question of how policy attitudes influence changes in opinion about the president. In so doing, it also considers the influence of partisanship as it is unwise to assess the influence of one without taking into account the other given the ongoing — and growing-association between the two (DiMaggio et al. 1996; Adams 1997; Abramowitz and Saunders 1998; Layman and Carsey 2002; Stimson 2004; Brewer 2005; Baldassarri and Gelman 2008; Bafumi and Shapiro 2009; Claassen and Highton 2009).
} 
usually has little rationale for its existence save as an instrument to further particular policy preferences. The policy is the end, and the party is the means" (Converse 1964, pp. 240-241). Thus, updating that brings opinions in line with policy attitudes may be interpreted as consistent with normative views about the proper role of the political process while updating influenced by partisanship is more problematic.

\section{Dynamic Accounts of Presidential Evaluations}

The immense literature on the causes of aggregate presidential approval serves as my starting point. Studies in this tradition emphasize the role of "valence issues" (Stokes 1963) like peace, prosperity, and security for explaining how presidential approval changes over time. On issues like these, there is consensus within the mass public about end goals and the public appears to evaluate the president on the basis of outcomes. Positive outcomes lead to heightened approval while negative outcomes produce lower approval, regardless of whether the president's actions are responsible (Kernell 1978; Hibbs et al. 1982; MacKuen 1983; Ostrom and Simon 1985; Brody 1991; Newman 2002; Erikson et al. 2002). When economic performance is strong and the country is at peace, presidential approval improves, and when the economy falters and unsuccessful war efforts continue, approval declines.

A straightforward individual level model of presidential evaluations implied by the aggregate studies is:

$$
E_{i t}=\alpha+\beta_{1} * E_{i, t-1}+\varepsilon_{i t}
$$

$E_{i t}$ denotes an individual's current evaluation of the president and $E_{i, t-1}$ denotes the individual's evaluation at an earlier time. Because evaluations are updated, not determined anew, $\beta_{1}$ is expected to be nonzero and positive. The effects of events during the period determine if there is a shift up $(\alpha>0)$ or down $(\alpha<0)$ in approval. Finally, random, individual disturbances $\left(\varepsilon_{i t}\right)$ influence current evaluations. ${ }^{3}$

If everyone responded to new events and information in a uniform manner, then (1) would be sufficient to model the process. But, the enormous literature on partisanship suggests that this is unlikely. In a famous passage, Campbell et al. (1960, p. 133) write that "identification with a party raises a perceptual screen through which the individual tends to see what is favorable to his partisan orientation." As mentioned earlier, the Columbia voting studies identified "selective exposure" as one mechanism by which partisanship might operate in this fashion (Lazarsfeld et al. 1948; Berelson et al. 1954). Recent research has elaborated on this notion. For example, the political leanings of the newspapers people read, talk radio programs they listen to, and internet sites they visit are all related to their political predispositions in a manner that is likely to reinforce, rather than challenge, those

\footnotetext{
3 The model in Eq. 1 and subsequent ones are models of change (Finkel 1995); $\alpha$ (and $\beta_{2}, \beta_{3}$, and $\beta_{4}$ in subsequent models) are parameters of change in $E$. Straightforward algebra shows this directly:

$$
\begin{aligned}
& E_{i t}=\alpha+\beta_{1} * E_{i, t-1}+\varepsilon_{i t} \\
& E_{i t}-E_{i, t-1}=\alpha+\beta_{1} * E_{i, t-1}-E_{i, t-1}+\varepsilon_{\mathrm{it}} \\
& \Delta E_{i}=\alpha+\left(\beta_{1}-1\right) * E_{i, t-1}+\varepsilon_{\mathrm{it}} .
\end{aligned}
$$


predispositions (Stroud 2008), a relationship that is likely growing stronger as media choices proliferate (Prior 2007). Studies of partisanship and social networks show that people are more likely to discuss politics with those who share their partisanship (Huckfeldt et al. 2004; Mutz 2006). ${ }^{4}$ In addition, work on information processing and "motivated reasoning" shows that people pay more attention to information that supports their views, they attach more weight to information that supports their views, they more easily accept information that is consistent with their preexisting views, they expend more cognitive effort to disconfirm information inconsistent with their preexisting views, and they construe the implications of the information in ways that are consistent with their preexisting views(Lodge and Taber 2000; Taber et al. 2001; Taber and Lodge 2006; Gaines et al. 2007).

One implication of "selective exposure" and "motivated reasoning" is that people may not update their evaluations of the president in the uniform way implied by Eq. 1. Suppose that the economy improves under a Republican president from $t-1$ to $t$. People who were Republicans at $t-1$ will probably give the president too much credit while people who were Democrats at $t-1$ may not give the president enough. Because partisanship shapes the information to which people are exposed and how they process it, "party bias" may be an important component for how people update their presidential evaluations.

Perhaps they rely on different sources of political information with distinctive partisan colorations. Perhaps they attach more salience to perceptions consistent with their partisan predispositions than to discordant perceptions. Whatever the mechanism (or mechanisms) may be, the result is that perceptions of political events are colored by pre-existing partisan loyalties (Bartels 2002, p. 24).

If there is party bias, then preexisting partisanship $\left(P I D_{t-1}\right)$ will influence how people update and revise their presidential evaluations in light of the information disseminated between $t-1$ and $t$ :

$$
E_{i t}=\alpha+\beta_{1} * E_{i, t-1}+\beta_{2} * P_{i, t-1}+\varepsilon_{i t}
$$

Party bias implies $\beta_{2} \neq 0$; those with different partisan attachments do not respond in the same way. 5

\section{Policy Attitudes and Presidential Evaluations}

There is consensus about desirable outcomes like peace, prosperity, and security. However, on questions about the best way to pursue them, there is often disagreement. "Position issues" (Stokes 1963) contrast with valence issues because they relate to the means employed to achieve policy goals, and people differ with

\footnotetext{
4 While there is some disagreement about the amount of partisan heterogeneity within social networks, there is widespread agreement that, in general, Democrats are more likely to discuss politics with Democrats and Republicans are more likely to talk about politics with Republicans.

5 Equation 2 is the model used in Bartels (2002). Lagged partisanship (rather than contemporaneous partisanship) is included to model the notion that current evaluations are influenced by the interaction of preexisting partisanship with new information.
} 
regard to their preferences and attitudes on position issues. For example, on issues about social welfare, some are economic liberals, favoring government efforts to reduce economic inequality and guarantee at least a minimal standard of living, and others are economic conservatives, preferring less government involvement and greater reliance on the free market. While it is not plausible that many people in the mass public have specific preferences over a range of specific policy questions within issue domains (Bartels 2003) there is strong evidence that on broader questions of policy (e.g., economic issues and cultural issues, in general) people have quite stable preferences and attitudes (Ansolabehere et al. 2008). ${ }^{6}$

Is it possible that people rely on their stable economic and cultural policy attitudes when they update their presidential evaluations? Theoretically, there are three conditions that must hold. First, for people to rely on issue attitudes, they must have them, and recent evidence suggests that they do (Ansolabehere et al. 2008; Layman and Carsey 2002). The second condition is that presidents must take positions on the issues. In the absence of presidential position taking, the opportunity to update assessments based on policy would not exist. Like the first condition, this one is met. Presidents are not only the standard bearers of their parties, and therefore plausibly the subject of party bias, presidents also differ with regard to the policies they advocate. Substantial differences in "position taking" (Mayhew 1974) are easy to document. As one indicator consider the DWNOMINATE (McCarty et al. 1997, 2006) scores for the three presidents who are the subject of the empirical analysis in this paper. These scores are based on public positions taken by presidents on bills voted on in Congress. They measure relative positions on an underlying ideological dimension that structures most of the roll call voting in Congress. These scores typically range from -1 (the most liberal) to +1 (the most conservative). The Republicans George H.W. Bush and George W. Bush are scored .64 and .70, respectively, on the DW-NOMINATE scale compared to .52 for the Democrat Bill Clinton. While there is intraparty variation, for the most part Republican presidents in recent American politics take conservative economic and cultural positions while Democrats take liberal ones.

The third necessary condition complements the second, relating to the opportunity to base presidential evaluations on policy attitudes. Presidential positions must be public and information about them disseminated to the mass citizenry. This condition also appears to be met. Through a wide variety of means, information about presidential positions may diffuse through the mass public. People read about politics in newspapers and on the internet; they listen to radio programs about politics; they watch network and cable news programs; and, even if they do not have direct media exposure, they often discuss politics with people who do. Certainly the general public forms distinctively different ideological

\footnotetext{
6 As discussed by both Bartels (2003) and Ansolabehere et al. (2008), the apparent influence of question wording and low over-time correlations for single policy questions are not inconsistent with the existence of real and enduring policy attitudes. To be sure, the case that people have preferences regarding specific policies within issue domains is harder to make convincingly than the case that people have preferences (or attitudes) regarding the broad issue domains like economics issues and cultural issues. I use the terms "policy preferences" and "policy attitudes" interchangeably to refer to the locations of people with regard to these general policy domains.
} 
Table 1 Perceived ideological locations of recent presidents

\begin{tabular}{llll}
\hline President & Years & $\begin{array}{l}\text { President's } \\
\text { perceived ideology }\end{array}$ & $\begin{array}{l}\text { Average perceived ideology of } \\
\text { president's party House members }\end{array}$ \\
\hline Bush (H.W.) & 1990,1992 & 4.9 & 4.8 \\
Clinton & $1994,1996,1998,2000$ & 3.1 & 3.7 \\
Bush (W.) & 2004 & 5.2 & 4.9 \\
\hline
\end{tabular}

Perceived ideology is measured with a scale ranging from 1 ("very liberal") to 7 ("very conservative"). Cell entries report the mean values across respondents. For comparability, only respondents who provided ideological ratings of the president and their House member are included. The questions were not asked in 2002

impressions of presidents as shown in Table 1. Using the standard NES question that asks respondents to use a seven point ideology scale ranging from 1 (very liberal) to 7 (very conservative), the table shows the average placement for each president along with the average placement given to House members from their respective parties. Notice that the differences between presidents from the two parties are larger than those for House members. The public perceives an ideological divide between Democratic and Republican presidents that is larger than the perceived divide between Democratic and Republican members of Congress.

With the necessary conditions for updating with respect to policy preferences likely met, the evaluation model should allow for the possibility:

$$
E_{i t}=\alpha+\beta_{1} * E_{i, t-1}+\beta_{2} * P I D_{i, t-1}+\beta_{3} * E_{C O N}{ }_{i, t-1}+\beta_{4} * C U L T_{i, t-1}+\varepsilon_{i t}
$$

Policy updating occurs with respect to economic policy attitudes (ECON) if $\beta_{3} \neq 0$ and cultural policy attitudes $(C U L T)$ if $\beta_{4} \neq 0$. Equally important is how $\beta_{3}$ and $\beta_{4}$ compare to $\beta_{2}{ }^{7}$ The normative significance derives not merely from establishing whether there is updating in response to issues, but from how the magnitude compares to the amount of party bias. ${ }^{8}$

Previous research also suggests the plausibility of policy updating. First, the theory of motivated reasoning can be extended to this area. Extant research shows that when presented with information that relates to what policy preferences they should hold, people tend to respond in a manner consistent with their prior beliefs. For example, citizens "who favor gun control or affirmative action rate congruent arguments as stronger than incongruent arguments, while those opposed see the con arguments as stronger" (Taber and Lodge 2006, p. 760). Thus there are psychological forces that operate to maintain one's partisanship and policy attitudes. When the object of evaluation is the president, these forces may work to produce updating with respect to

\footnotetext{
7 As in the case of partisanship, lagged policy attitudes are included rather than contemporaneous ones to capture the notion that people respond to the information disseminated between $t-1$ and $t$ on the basis of their preexisting attitudes $\left(E C O N_{t-1}, C U L T_{t-1}\right.$, and $\left.P I D_{t-1}\right)$. To the extent that attitudes change between $t-1$ and $t$ and those changes in attitudes influence $E_{t}$, model (3) is incomplete. However, the impressive stability of partisan and policy attitudes over the short-term suggests that attitude change is minimal, mitigating — at least to some degree — this concern (Ansolabehere et al. 2008).

${ }^{8}$ Related, given that partisanship and policy attitudes are correlated, the inclusion of policy attitudes may diminish the apparent effects of partisanship. This, in turn, would suggest that the exclusion of policy attitudes from the model — as is often the case in previous research-leads to an overestimate of the magnitude of party bias. I return to this point later.
} 
policy. For example, consider a Democratic president who takes liberal positions on economic policy. As discussed earlier, Democrats and Republicans should respond differently to information regarding valence issues. At the same time, given the psychological importance people appear to attach to their policy views, one would expect economic liberals to react more favorably than economic conservatives (independent of partisanship).

A second reason suggesting the plausibility that policy updating occurs is found in cross-sectional studies of presidential evaluations and voting behavior. When policy preferences are included in these models, nontrivial effects are often reported (Newman 2003; Abramowitz 1995; Aldrich et al. 1989; Miller and Shanks 1996; Ansolabehere et al. 2008; Goren 2002). While this does not automatically imply that policy attitudes influence how people revise their presidential assessments, it certainly raises the possibility. Third, studies of presidential evaluations in the wake of major political events are also suggestive. For instance, one study compared the crosssectional structure of the public's assessments of President Reagan before and after the revelation that his administration had secretly diverted money from arms sales to Iran to support the Nicaraguan Contras (Krosnick and Kinder 1990). After the revelation and the massive media coverage of it, the alignment between foreign policy attitudes and assessments of Reagan were stronger than before. Krosnick and Kinder attribute the change to the substantial media coverage of the event that "primed" policy attitudes by providing relevant information and enhancing their salience. Another study is similar (Peffley et al. 1995). Peffley et al. (1995) focuses on the U.S. bombing of Libya in 1986 and using panel data collected before and after the bombing find that preexisting foreign policy attitudes shaped whether people approved of the bombing, which in turn, influenced how people updated their presidential evaluations. ${ }^{9}$ Both studies suggest that dramatic political events may prime policy attitudes as a result of the media attention they generate. ${ }^{10}$ What remains unknown is what happens in the absence of a "highly publicized and dramatic revelation" (Krosnick and Kinder 1990, p. 498) or a "highly publicized [event]... followed by a dramatic televised [presidential] address" (Peffley et al. 1995, p. 309). If policy updating is limited to instances like these, then it is hardly the case that policy attitudes routinely shape how people revise their presidential assessments as day-to-day political events unfolds.

While there is a plausible case for policy updating to be made, it should also be noted that some previous research raises doubt and expresses skepticism. The

\footnotetext{
${ }^{9}$ A third study also analyzes the role of "policy attitudes" for shaping responses to a dramatic political event (Edwards and Swenson 1997). However, the measures of policy attitudes employed in Edwards and Swenson (1997) when analyzing the missile attack on Iraq's intelligence headquarters in 1993 are better characterized as preexisting presidential evaluations; the questions are less about policy means and more about assessing the president. For example, the items included in the measure of foreign policy attitudes "include evaluations of Clinton's handling of foreign policy in general, particularly that of Yugoslavia and Somalia, and the levels of confidence and trust in his handling of international crises" (Edwards and Swenson 1997, p. 203).

${ }^{10}$ Because Krosnick and Kinder (1990) rely on cross-sectional data collected before and after the revelation, one cannot be sure that policy attitudes were actually primed. If people who already had positive evaluations of Reagan updated their policy attitudes in response to the revelations then causality runs in the other direction. Peffley et al. (1995) is stronger in this regard because it relies on panel data with policy attitudes measured prior to the political event.
} 
authors of the American Voter did not just contend that "responses to each element of national politics are deeply affected by the individual's enduring party attachments" (Campbell et al. 1960, p. 128). They argued that "the stable qualities of the public's response to political affairs have to do primarily with long-term loyalties to the parties rather than ideological commitments against which current acts or policies of the parties could be evaluated" (Campbell et al. 1960, emphasis added). In a similar vein, an influential and more recent study (Rahn 1993) claims that "when voters have both particular [policy] information and party stereotypes available... [they] neglect policy information in reaching evaluations" (Rahn 1993, p. 492). Other studies have analyzed updating with regard to partisanship without considering issues (Markus 1982; Finkel 1993; Bartels 2002), implicitly assuming that policy updating is not an important part of the process.

\section{Data and Measures}

The primary empirical aim of this paper is to estimate the influence of policy attitudes on how people revise their presidential assessments. To do this I rely on American National Election Study (ANES) panel datasets that span three recent presidencies. The 1990-91-92 panel covers the last 2 years of George H.W. Bush's administration. The 1992-94-96 panel spans the first 4 years of the Clinton presidency. The 2000-02-04 covers the first term of George W. Bush's administration. For each president, there are two opportunities to observe and estimate the parameters of updating in Eq. 3, from the first year of the panel to the second, and from the second year of the panel to the third. By examining six cases across three different presidencies that vary by (a) party of president, (b) whether overall presidential assessments improved or declined, and (c) the amount of aggregate change, the possibility of mistakenly attributing idiosyncratic effects to more general processes is reduced. ${ }^{11}$

To measure policy attitudes, I follow Ansolabehere et al. (2008), which recommends creating multiple indicator scales of broad issue preferences on the grounds that while individual items tend to include substantial measurement error, scales based on many items produce far more "signal" than "noise." ${ }^{12}$ Specifically, the procedure in Ansolabehere et al. (2008) involves (i) identifying all available questions in a survey for a designated policy area, (ii) factor analyzing those items, and (iii) computing factor scores for the first factor, which serve as measures for subsequent analyses. ${ }^{13}$ The result is a scale that differentiates respondents with more liberal issue orientations from those with more conservative tendencies. For

\footnotetext{
11 At the same time, these are the only panel studies that are available for analysis that meet the necessary data requirements to estimate the assessment models.

12 See also Bartels (2010). Abramowitz (2010) does something similar, creating an issue scale based on a large number of available items. One important difference is that Abramowitz combines economic and cultural items into a single scale while Ansolabehere et al. (2008) and Bartels (2010) create separate policy attitude scales.

13 As Ansolabehere et al. (2008) note, they consistently find a single dominant dimension within issue domains. There do not appear to be multiple economic dimensions or multiple cultural dimensions.
} 
example, for the economic attitudes scales, questions asking respondents to choose a preferred position or location on specific items like whether the government should guarantee people jobs and whether federal spending on the poor should be increased or decreased along with more general questions about egalitarianism and the proper role of government are included. ${ }^{14}$ The cultural issue scales typically include questions about abortion policy, laws regarding the treatment of homosexuals, and views regarding morality. ${ }^{15}$ The complete lists of questions used to create all of the issue scales are provided in the Appendix. ${ }^{16}$

To measure partisanship I rely on three items, also following Ansolabehere et al. (2008). The first is based on the standard ANES questions that ask respondents whether they consider themselves Democrats or Republicans, whether those feelings are strong, and if respondents do not consider themselves partisans, whether they feel closer to one of the two parties. The second and third items are feeling thermometers for the respective parties. Factor scores based on factor analyses of the three items serve as the measure of partisanship. ${ }^{17}$

Previous research establishes clear links between partisanship and issue preferences that have grown stronger over time, especially with regard to cultural issues (DiMaggio et al. 1996; Adams 1997; Abramowitz and Saunders 1998; Layman and Carsey 2002; Stimson 2004; Brewer 2005; Baldassarri and Gelman 2008; Bafumi and Shapiro 2009; Claassen and Highton 2009; Abramowitz 2010). These patterns are evident in the data used here; the average correlation between partisanship and economic attitudes is .56; the average correlation between partisanship and cultural attitudes is $.35 .{ }^{18}$ In light of these correlations the interpretations of the effects of issues and partisanship on presidential evaluations are based on the estimated effects of moving one standard deviation on the scales rather than across the full ranges of the respective scales.

To measure evaluations $(E)$, I rely on a variety of indicators in the ANES surveys. The most commonly asked question (included in every wave of every

\footnotetext{
${ }^{14}$ By including more general items that indicate what have been called "core beliefs and values" (Feldman 1988) and "policy related predispositions" (Miller and Shanks 1996), the policy scales are broader than those typically used in previous research. This decision was based on several considerations. Bartels (2003) argues that due to framing effects, question wording effect, and a host of other factors, the answers people give in response to even narrow questions about policy reveal more about general "attitudes" than specific policy preferences. Likewise Ansolabehere et al. (2008) finds that specific and general questions within policy domains are indicators of underlying, latent, issue orientations.

${ }^{15}$ Because there substantially fewer cultural items included in the surveys, following Ansolabehere et al. (2008) I also include some group thermometer items (e.g., "the women's movement" and "gay men and lesbians") in the scale of cultural attitudes.

16 There were hardly any policy attitude questions included in the 1991 and 2002 surveys. As a result when predicting change in presidential assessments from 1991 to 1992, I employ the measures of policy attitudes from 1990 and when predicting change in assessments from 2002 to 2004 I use the measures of policy attitudes from 2000. Because of the high stability in policy attitudes over short periods of time (Ansolabehere et al. 2008), this is unlikely to be problematic.

17 The apparent influence of partisanship is somewhat larger when using the partisanship factor scores instead of the traditional seven point measure of partisanship alone.

18 There is not much change in the partisanship/economic attitudes correlation across the surveys, but the partisanship/cultural attitudes correlation increases from .23 in the 1990-1992 panel to .44 in the 2000-2004 panel.
} 
survey) is the feeling thermometer, which asks respondents to rate the person on a 100 point scale. Questions about presidential approval are also asked in every survey, but because Clinton and Bush had not yet served in 1992 and 2000, respectively, this indicator is not available for them in those years. The ANES surveys also frequently ask respondents about how well traits like "honest" and "gets things done" describe presidents and presidential candidates. A fourth type of question asks about emotions (e.g., "angry" and "hopeful") people have felt with regard to presidents and presidential candidates. For each of the three panels I identify all the indicators of assessments available. Where there are multiple indicators in the same question format (e.g., a set of trait questions) I compute the average response to those questions. To produce a composite presidential evaluation measure $\left(E_{i t}\right)$, for each individual in each panel wave, I factor analyze the items and compute factors scores from the first factor. ${ }^{19}$

Respondents are included in the analysis if they were interviewed in all three waves of their respective panels and if they answered at least $50 \%$ of the questions that comprise each of policy, partisanship, and evaluation scales. Limiting the analysis to respondents interviewed in all three waves guarantees that any differences in the effect estimates from one wave to the next are not due to sample composition differences. ${ }^{20}$ Limiting the analysis to people who answered at least $50 \%$ of the items in each of the scales reduces the number of cases only marginally, by less than $2 \%$ in each of the three panels. ${ }^{21}$ The resulting sample sizes for the analyses of the 19901992, 1992-1996, and 2000-2004 panels are 535, 592, and 744, respectively.

\section{Findings}

Table 2 provides the parameter estimates of Eq. 3 for the six cases across the three presidencies. $^{22}$ The first column of estimates in Table 2 reports the results for President Bush from 1990-1991 and shows that both economic and cultural policy attitudes influenced change in presidential evaluations. The estimate of $\beta_{3}$ (.062, standard error $=.031$ ) suggests divergent change associated with economic policy attitudes; a difference of one standard deviation in economic preferences in 1990

\footnotetext{
19 In all the surveys a single dominant factor emerged. See the Appendix for the patterns of eigenvalues, which demonstrate the point.

20 This is important, for example, when comparing the effects from 1992-1994 when Clinton changed from being a presidential candidate to the president to those from 1994-1996. To be sure, restricting the sample in this way does carry the disadvantage of making the sample less representative, which limits the generalizability of the findings in the same way that survey non-response does.

21 Following Ansolabehere et al. (2008), imputations based on best-subset linear regression were used for respondents with missing data on individual items. In the 1990-91-92 panel respondents were randomly assigned to "form A" or "form B." Form B respondents were not asked most of the policy attitude questions and are therefore excluded from the analysis.

22 The variables were standardized to have a mean of zero and a standard deviation of one. Hence the cell entries indicate the estimated effect of moving one standard deviation across the independent variables. In addition all the variables were recoded so higher values are associated with more positive evaluations. Thus, for Clinton, higher scores for partisanship and policy preferences indicate more Democratic and liberal preferences. For the Bushes, higher scores indicate more Republican and conservative preferences.
} 
Table 2 Parameter estimates of presidential evaluations

\begin{tabular}{|c|c|c|c|c|c|c|}
\hline & $\begin{array}{l}\text { H.W. Bush } \\
1990-1991\end{array}$ & $\begin{array}{l}\text { H.W. Bush } \\
1991-1992\end{array}$ & $\begin{array}{l}\text { Clinton } \\
\text { 1992-1994 }\end{array}$ & $\begin{array}{l}\text { Clinton } \\
\text { 1994-1996 }\end{array}$ & $\begin{array}{l}\text { W. Bush } \\
2000-2002\end{array}$ & $\begin{array}{l}\text { W. Bush } \\
\text { 2002-2004 }\end{array}$ \\
\hline Prior evaluation $\left(\hat{\beta}_{1}\right)$ & $\begin{array}{l}.608 * * \\
(.032)\end{array}$ & $\begin{array}{l}.510 * * \\
(.034)\end{array}$ & $\begin{array}{l}.399 * * \\
(.042)\end{array}$ & $\begin{array}{l}.652 * * \\
(.035)\end{array}$ & $\begin{array}{l}.564 * * \\
(.038)\end{array}$ & $\begin{array}{l}.641^{* *} \\
(.024)\end{array}$ \\
\hline Prior partisanship $\left(\hat{\beta}_{2}\right)$ & $\begin{array}{l}.142 * * \\
(.034)\end{array}$ & $\begin{array}{l}.214 * * \\
(.034)\end{array}$ & $\begin{array}{l}.223 * * \\
(.043)\end{array}$ & $\begin{array}{l}.142 * * \\
(.036)\end{array}$ & $\begin{array}{l}.139 * * \\
(.040)\end{array}$ & $\begin{array}{l}.210 * * \\
(.027)\end{array}$ \\
\hline $\begin{array}{l}\text { Prior economic } \\
\text { attitudes }\left(\hat{\beta}_{3}\right)\end{array}$ & $\begin{array}{l}.062 * * \\
(.031)\end{array}$ & $\begin{array}{l}.175 * * \\
(.032)\end{array}$ & $\begin{array}{l}.162 * * \\
(.038)\end{array}$ & $\begin{array}{l}.096 * * \\
(.031)\end{array}$ & $\begin{array}{l}.082 * * \\
(.032)\end{array}$ & $\begin{array}{l}-.016 \\
(.024)\end{array}$ \\
\hline $\begin{array}{l}\text { Prior cultural } \\
\text { attitudes }\left(\hat{\beta}_{4}\right)\end{array}$ & $\begin{array}{l}.146^{* * *} \\
(.030)\end{array}$ & $\begin{array}{l}.060^{*} \\
(.031)\end{array}$ & $\begin{array}{l}.081 * * \\
(.031)\end{array}$ & $\begin{array}{l}.024 \\
(.026)\end{array}$ & $\begin{array}{l}.029 \\
(.030)\end{array}$ & $\begin{array}{l}.161 * * \\
(.021)\end{array}$ \\
\hline $\begin{array}{l}\text { Joint policy effects: } \\
\text { prior economic } \\
+ \text { prior cultural } \\
\text { attitudes }\left(\hat{\beta}_{3}+\hat{\beta}_{4}\right)\end{array}$ & $\begin{array}{l}.207 * * \\
(.039)\end{array}$ & $\begin{array}{l}.235 * * \\
(.041)\end{array}$ & $\begin{array}{l}.242^{* *} \\
(.043)\end{array}$ & $\begin{array}{l}.121 * * \\
(.035)\end{array}$ & $\begin{array}{l}.111 * * \\
(.039)\end{array}$ & $\begin{array}{l}.145^{* *} \\
(.029)\end{array}$ \\
\hline$N$ & 535 & 535 & 592 & 592 & 744 & 744 \\
\hline$R^{2}$ & .58 & .56 & .54 & .70 & .53 & .74 \\
\hline
\end{tabular}

All variables are standardized, and as a result the estimated intercepts are equivalent to zero and therefore not reported in the table. $* * p<.05 ; * p<.10$

produced a difference in presidential evaluation change of .062 in 1991. Divergent updating with regard to cultural policy attitudes is even more pronounced with an estimated effect of .146 for a one standard deviation difference in cultural policy preferences $\left(\hat{\beta}_{4}=.146\right.$, standard error $\left.=.060\right)$. The influences of economic and cultural policy attitudes suggest that people do not only respond to valence issuesif they did, then $\beta_{3}=0$ and $\beta_{4}=0$ - but that policy information was an important component of the information environment between the 1990 and 1991.

The estimates in Table 2 also indicate the presence of party bias as Democrats and Republicans (independent of their respective policy attitudes) did not have a shared response to political events between 1990 and $1991\left(\hat{\beta}_{2}=.142\right.$, standard error $=.034)$. The party bias estimate also helps to put the effects of policy preferences in perspective. The difference in response associated with economic preferences (.062) was a bit less than half the party bias effect while the influence of cultural issues (.146) was essentially equal to the effect of party bias.

As it turns out, across the six cases spanning the three presidencies, the pattern observed for updating evaluations of Bush from 1990 to 1991 is fairly typical. Consistent with previous research (Bartels 2002), a regular influence of party bias is evident. Across the six tests, the average party bias estimate is .178 , and in all six instances the null hypothesis of no party bias can be rejected at the .05 level. What is new are the estimated effects of policy attitudes on updating. In all of the cases except 2002-2004, there is strong evidence that economic attitudes influenced how people updated their evaluations $(p<.05)$. The average effect of .094 is bit more than half the average effect of partisanship. ${ }^{23}$ Updating with respect to cultural attitudes is also

\footnotetext{
${ }_{23}$ Across the five cases-excluding 2002-2004_the average effect of economic attitudes is .115.
} 
Table 3 Estimated effects of prior partisanship on presidential evaluations

\begin{tabular}{llllllll}
\hline & $\begin{array}{l}\text { H.W. Bush } \\
1990-1991\end{array}$ & $\begin{array}{l}\text { H.W. Bush } \\
1991-1992\end{array}$ & $\begin{array}{l}\text { Clinton } \\
1992-1994\end{array}$ & $\begin{array}{l}\text { Clinton } \\
1994-1996\end{array}$ & $\begin{array}{l}\text { W. Bush } \\
\text { 2000-2002 }\end{array}$ & 2002-2004 Bush & Average \\
\hline $\begin{array}{l}\text { Effect of prior partisanship } \\
\begin{array}{l}\text { From model } \\
\text { with policy } \\
\text { attitudes }\end{array}\end{array}$ & .142 & .214 & .223 & .142 & .139 & .210 & .178 \\
$\begin{array}{l}\text { From model } \\
\text { without } \\
\text { policy } \\
\text { attitudes }\end{array}$ & .188 & .278 & .291 & .189 & .185 & .248 & .230 \\
\hline
\end{tabular}

Cell entries report the estimated effects of prior partisanship on presidential evaluations. The entries for "From model with policy attitudes" are from Table 2. The entries for "From model without policy attitudes" are based on reestimating the models after excluding policy attitudes

apparent. In four of the six cases (all but 1994-1996 and 2000-2002) the null hypothesis of no effect can be rejected at either the .05 (1990-1991, 1992-1994, 2002-2004) or .10 (1991-1992) levels. Across all the cases, the average effect of .084 for cultural policy attitudes is just modestly smaller than the average effect of economic preferences.

In addition to the separate effects of each policy attitude, Table 2 also reports the estimated joint policy effects, which are the sums of separate effects. While economic attitudes and cultural attitudes appear influential on their own, taken together their effects are on par with those of partisanship. The joint effects range from .111 (2000-2002) to .242 (1992-1994), which is very similar to the range of .139 (2000-2002) to .223 (1992-1994) for partisanship. Likewise the average joint effect of policy attitudes is almost identical to the average effect of partisanship, .177 versus .178. The largest observed difference is for 2002-2004 where the estimate of party bias is . 210 and the estimated joint issue effect is .145. Even in this case, a statistical test of the null hypothesis of no difference between the partisanship and joint policy effect cannot be rejected at conventional levels $(p=.17)$.

Because partisanship is correlated with economic and cultural attitudes, evaluation models like Eq. 2 that exclude the possibility of policy updating may exaggerate the magnitude of "party bias." To determine how much the influence of partisanship is overestimated when policy attitudes are excluded, I estimated Eq. 2 for the six cases under study here. Table 3 reports the results and compares them to the ones from Table 2 that are based on Eq. 3, which includes policy attitudes. In every case the estimated magnitude of party bias is larger when policy attitudes are excluded with the average effect of .230 about $30 \%$ larger than the average effect of .178 when policy attitudes are included. Although not trivial, this does not suggest that previous studies like Markus (1982), Finkel (1993) and Bartels (2002) are fundamentally wrong about party bias. Instead, previous work that does not model policy updating is better characterized as incomplete, missing an important process by which people revise their evaluations.

Finally, while the dependent variables in all instances are presidential evaluations, in two cases (Bill Clinton in 1992-1994 and George W. Bush in 2000-2002) the measure of prior evaluations is from the presidential campaign before the presidency 
had even begun. As a consequence, one might expect prior evaluations to matter less, and in both cases this appears to be the case. For Clinton from 1992-1994 to 1994-1996 the estimated influence of prior evaluations increases from .399 to .652; for Bush from 2000-2002 to 2002-2004 the estimated influence increases from .564 to .641. Moreover, the overall explained variation $\left(R^{2}\right)$ also increases from the first to second periods, from .54 to .70 for Clinton and from .53 to .74 for Bush. However, there are no clear patterns with regard to the influence of partisanship and policy attitudes. In the case of Clinton, the increased influence of prior evaluations is associated with diminished effects partisanship and policy attitudes, but the same is not the case for Bush, suggesting no simple explanation for the interplay of forces as the objects of evaluation move from presidential candidates to presidents. $^{24}$

\section{Discussion and Conclusion}

Accounts of public opinion and voting behavior often give prominence to "the role of enduring partisan commitments in shaping attitudes toward political objects" (Campbell et al. 1960, p. 135). The proposition that people respond to new political events and information on the basis of their preexisting partisanship and revise their political evaluations accordingly is well grounded theoretically and has received ample empirical support. Typically left unexamined has been the role that policy attitudes play when citizens update their political evaluations. For example, Bartels (2002) conducts "92 distinct analyses of opinion change" to investigate the "pervasiveness of partisan bias in political perceptions and evaluations" (p. 130). While party bias does appear pervasive - a finding reinforced in this paper-none of the analyses in Bartels (2002) allows for the possibility that opinion change is related to policy attitudes. Yet, presidents regularly engage in public position taking, providing information about their policy priorities and positions. By analyzing six cases across three presidencies, this paper has gone a long way toward making the case that policy attitudes exert a regular and consequential influence on how people respond to the president. Repeatedly, policy attitudes emerge as forces that shape how people update their presidential assessments. Whereas previous research has shown that in the wake of dramatic political events that receive extraordinary political attention citizens' policy attitudes have influenced how they update their opinions, the findings reported here suggest that policy updating is more common and therefore consequential.

This paper's results also provide insight into an important scholarly disagreement (Gerber and Green 1998, 1999; Bartels 2002). Gerber and Green (1998, 1999) observe that shifts in presidential approval among Democrats and Republicans are typically in the same direction and of the same magnitude, and from this they infer that there is no party bias in how people update their presidential evaluations. They contend that if there was bias, then growing divergence would be evident. Bartels (2002) argues that if people agree about the implications for presidential approval of new information, then over time there would be convergence between Democrats

\footnotetext{
${ }^{24}$ Further, as noted in the Appendix, if 1992-1994 and 2000-2002 are excluded and the dependent variable is presidential job approval (with lagged job approval as the measure of preexisting evaluations), the patterns of results follow those in Table 2 .
} 
and Republicans. For Bartels, the lack of convergence evident in parallel movements implies party bias. This claim would rest on firmer footing if the information provided to the public was only valence information. When valence and policy information are disseminated, as is typically the case in day-to-day politics, lack of convergence may also imply policy updating because Democrats and Republicans differ with regard to their policy preferences, with Democrats holding more liberal economic and cultural attitudes and Republicans holding more conservative ones. The meaning of parallel movements depends on the nature of the information provided and the type or types of updating that occur among individuals.

The results reported in this paper also speak to an important question about "motivated reasoning" (Lodge and Taber 2000; Taber et al. 2001; Taber and Lodge 2006). Previous work emphasizes how having a psychological stake in an attitude can lead an individual to distort new information to make it consonant with a preexisting attitude, be that attitude about partisanship or policy. Indeed, motivated reasoning may be the (or at least $a$ ) causal force that underlies the often noted consistency in individual partisanship and policy attitudes (Green et al. 2002; Goren 2005; Ansolabehere et al. 2008). The implications of motivated reasoning in the context of presidential evaluations require paying attention to the fact that presidents are party leaders who also engage in position taking. Because presidents are party leaders, citizens have an incentive to update and revise their presidential evaluations in light of their partisanship. At the same time, the importance of policy attitudes appears to motivate people to update presidential evaluations based on the policy information provided through presidential position taking. But, responding to the president on the basis of one's policy preferences has normatively different implications than responding to the president on the basis on partisanship as reason noted at the outset of this paper. The ultimate payoff from politics is policy. As Lasswell (1936) famously put it, politics is about "who gets what, when, and how." Parties are important as the means through which the ends are obtained (Converse 1964). Consequently, while distorting new information in order to maintain a policy preference that would otherwise need to be changed is of a piece with distorting new information in order to reinforce one's partisanship, updating one's view of the president in response to the president's policy signals is quite normatively different than updating one's view of the president in response to the president's party affiliation.

Finally, the finding that policy updating occurs alongside party bias carries important substantive implications. If there was party bias without policy updating, then over time partisanship would becomes an ever increasing component of evaluations. To the extent that citizens' policy preferences coincide with their partisanship (liberal preferences for Democrats and conservative preferences for Republicans) and the President takes position consistent with his party, then party bias would have the effect of bringing one's policy preferences into alignment with one's presidential evaluations. But, while partisanship and policy preferences have become more closely related over time, they remain far from perfectly correlated (DiMaggio et al. 1996; Adams 1997; Abramowitz and Saunders 1998; Layman and Carsey 2002; Stimson 2004; Brewer 2005; Baldassarri and Gelman 2008; Bafumi and Shapiro 2009; Abramowitz 2010). Consequently, in the absence of policy updating, a commonly aspired to form of democratic accountability, whereby 
elected officials are evaluated on the basis of the policy positions they take rather than their partisanship, would be absent. Many people with conservative policy attitudes would come to look favorably on relatively liberal Democratic presidents and unfavorably on Republican presidents just as some people with liberal attitudes would assess Republican presidents more positively than Democratic ones.

In conclusion, this paper does not challenge the proposition that partisanship is a potent force influencing how the mass public responds to political events, but it does suggest that accounts of mass politics that do not consider policy attitudes are incomplete and misleading. In the case of the president, whatever the ingredients of citizens' initial assessments and opinions, they appear to update those evaluations in response to policy information.

Open Access This article is distributed under the terms of the Creative Commons Attribution Noncommercial License which permits any noncommercial use, distribution, and reproduction in any medium, provided the original author(s) and source are credited.

\section{Appendix}

\section{Measurement of Policy Attitudes}

As described in the main text, to create a composite measure of Evaluations $(E)$, I combined responses across a variety of question formats and domains and then used factor analysis to produce factor scores, which were subsequently used in the analysis. In all cases, a single dominant factor emerged as indicated by the large eigenvalues for the first factor and the small eigenvalues for the second, as reported in Table 7.

As described in the main text, I followed Ansolabehere et al. (2008) when creating the measures of economic and cultural policy attitudes. The specific items used in the scales are listed in Tables 4 and 5. Missing values were imputed using best-subset linear regression, also following Ansolabehere et al. (2008). Without imputation, the number of lost respondents would have been substantial. For example, for 1990 only $55 \%$ of respondents answered all the economic and cultural policy questions. ${ }^{25}$ For 1992, 1994, and 2000, the respective percentages were 41, 64, and 25. At the same time, most respondents did provide answers to most questions as shown in Table 6 . Within policy domains typically majorities (and often large majorities) answered all the questions. Of those who had at least one missing value, the vast majority had missing values for less than $25 \%$ of the items.

\section{Dimensionality of Presidential Evaluations}

As described in the main text, to create a composite measure of Evaluations $(E)$, I combined responses across a variety of question formats and domains and then used factor analysis to produce factor scores, which were subsequently used in the analysis. In all cases, a single dominant factor emerged as indicated by the large

\footnotetext{
${ }_{25} 62 \%$ of respondents answered all the economic questions; $83 \%$ answered all the cultural ones; and, $55 \%$ all the economic and all the cultural ones.
} 
eigenvalues for the first factor and the small eigenvalues for the second, as reported in Table 7.

\section{Job Approval}

Job approval is the traditional measure used in studies of presidential evaluations, especially at the aggregate level. To determine if the findings reported in Table 2 are consistent with what one would find if evaluations are based only on job approval, I reestimated the models using job approval only as the indicator of evaluations. The results are reported in Table 8 and are consistent with those reported in Table 2 based on the full set of evaluation items. (Note: In two instances-1992-1994 and 2000-2002 - there is no measure of prior job approval because Bush and Clinton were not yet president in 1992 and 2000, respectively.

Table 4 Indicators of economic policy preferences

\begin{tabular}{|c|c|c|c|c|c|c|}
\hline Item & Most liberal & $\begin{array}{l}\text { Most } \\
\text { conservative }\end{array}$ & 1990 & 1992 & 1994 & 2000 \\
\hline $\begin{array}{l}\text { Strong government v. free } \\
\text { market }\end{array}$ & Strong gov. & Free market & v900331 & v925730 & & p001421 \\
\hline Reason for poverty & $\begin{array}{l}\text { Beyond indiv. } \\
\text { control }\end{array}$ & $\begin{array}{l}\text { Lack of hard } \\
\text { work }\end{array}$ & v900332 & & & \\
\hline Size of government & More & Less & v900333 & v925729 & & p001420 \\
\hline Why government is big & Big problems & Too involved & v900335 & v925731 & & p001422 \\
\hline $\begin{array}{l}\text { Fed spending on } \\
\text { environment }\end{array}$ & Increase & Decrease & v900377 & v923815 & v940817 & p000682 \\
\hline Fed spending on AIDS & Increase & Decrease & v900379 & v923727 & v940821 & p000677 \\
\hline $\begin{array}{l}\text { Fed spending on Social } \\
\text { Security }\end{array}$ & Increase & Decrease & v900380 & v923811 & v940819 & p000681 \\
\hline $\begin{array}{l}\text { Fed spending on food } \\
\text { stamps }\end{array}$ & Increase & Decrease & v900382 & v923725 & v940822 & p000679 \\
\hline $\begin{array}{l}\text { Fed spending on public } \\
\text { schools }\end{array}$ & Increase & Decrease & v900383 & v923818 & v940823 & p000683 \\
\hline Fed spending on homeless & Increase & Decrease & v900384 & v923730 & & \\
\hline Fed spending on childcare & Increase & Decrease & v900385 & v923813 & v940824 & p000685 \\
\hline $\begin{array}{l}\text { Fed spending on aid to } \\
\text { blacks }\end{array}$ & Increase & Decrease & v900386 & v923729 & & p000687 \\
\hline Fed spending on welfare & Increase & Decrease & & v923726 & v940820 & p000676 \\
\hline $\begin{array}{l}\text { Fed spending in financial } \\
\text { aid }\end{array}$ & Increase & Decrease & & v923728 & & \\
\hline $\begin{array}{l}\text { Fed spending on } \\
\text { unemployed }\end{array}$ & Increase & Decrease & & v923816 & & \\
\hline Fed spending on poor & Increase & Decrease & & v923817 & & p000680 \\
\hline $\begin{array}{l}\text { Fed spending on aid to big } \\
\text { cities }\end{array}$ & Increase & Decrease & & v923819 & & \\
\hline $\begin{array}{l}\text { Fed spending on health } \\
\text { care }\end{array}$ & Increase & Decrease & & & v940826 & \\
\hline
\end{tabular}


Table 4 continued

\begin{tabular}{|c|c|c|c|c|c|c|}
\hline Item & Most liberal & $\begin{array}{l}\text { Most } \\
\text { conservative }\end{array}$ & 1990 & 1992 & 1994 & 2000 \\
\hline Fed spending on defense & Decrease & Increase & & & v940827 & \\
\hline Guaranteed equal opp. & Strong agree & Strong disagree & v900426 & v926024 & v940914 & p001521 \\
\hline $\begin{array}{l}\text { Equal rights pushed too } \\
\text { far }\end{array}$ & Strong disagree & Strong agree & v900427 & v926025 & v940915 & p001522 \\
\hline $\begin{array}{l}\text { Lack of equal chance a } \\
\text { problem }\end{array}$ & Strong agree & Strong disagree & v900428 & v926027 & v940916 & p001523 \\
\hline $\begin{array}{l}\text { Country better if worry } \\
\text { less about equality }\end{array}$ & Strong disagree & Strong agree & v900429 & v926025 & v940917 & p001524 \\
\hline $\begin{array}{l}\text { Not a problem if some } \\
\text { have better change }\end{array}$ & Strong disagree & Strong agree & v900430 & v926029 & v940918 & p001525 \\
\hline $\begin{array}{l}\text { Equal treatment means } \\
\text { fewer problems }\end{array}$ & Strong agree & Strong disagree & v900431 & v926028 & v940919 & p001526 \\
\hline Spending on defense & Greatly decrease & $\begin{array}{l}\text { Greatly } \\
\text { increase }\end{array}$ & v900439 & v923707 & v940929 & \\
\hline Guaranteed std. of living & $\begin{array}{l}\text { Gov. should } \\
\text { provide }\end{array}$ & $\begin{array}{l}\text { Gov. should not } \\
\text { provide }\end{array}$ & v900446 & v923718 & v940930 & \\
\hline Gov. aid to blacks & Gov. should help & $\begin{array}{l}\text { Blacks should } \\
\text { help selves }\end{array}$ & v900447 & v923724 & v940936 & \\
\hline Gov. services & $\begin{array}{l}\text { Gov. provide } \\
\text { many more }\end{array}$ & $\begin{array}{l}\text { Gov. provide } \\
\text { many fewer }\end{array}$ & v900452 & v923701 & v940940 & p001390 \\
\hline $\begin{array}{l}\text { Tax increase for } \\
\text { environment }\end{array}$ & Strongly support & $\begin{array}{r}\text { Strongly } \\
\text { oppose }\end{array}$ & v900487 & & & \\
\hline $\begin{array}{l}\text { Gov. child care to low } \\
\text { income }\end{array}$ & Should provide & $\begin{array}{l}\text { Should not } \\
\text { provide }\end{array}$ & v900488 & v923745 & & \\
\hline $\begin{array}{l}\text { What to do with defense } \\
\text { money }\end{array}$ & $\begin{array}{l}\text { Increase } \\
\text { spending }\end{array}$ & Reduce deficit & v900490 & & & \\
\hline Health insurance & $\begin{array}{l}\text { Gov. insurance } \\
\text { plan }\end{array}$ & $\begin{array}{l}\text { Private } \\
\text { insurance } \\
\text { plan }\end{array}$ & & v923716 & v940950 & \\
\hline Parental leave & $\begin{array}{l}\text { Gov. should } \\
\text { require }\end{array}$ & $\begin{array}{l}\text { Left to } \\
\text { individual } \\
\text { employer }\end{array}$ & & v923717 & & \\
\hline $\begin{array}{l}\text { How do deal with urban } \\
\text { unrest }\end{array}$ & $\begin{array}{l}\text { Solve poverty/ } \\
\text { unemployment }\end{array}$ & $\begin{array}{l}\text { Use all } \\
\text { available } \\
\text { force }\end{array}$ & & v923746 & & \\
\hline Willingness to pay taxes & $\begin{array}{l}\text { Pay more for } \\
\text { more services }\end{array}$ & Keep same & & v925922 & & \\
\hline $\begin{array}{l}\text { Willingness to expand } \\
\text { Medicare }\end{array}$ & Favor strongly & $\begin{array}{l}\text { Oppose } \\
\text { strongly }\end{array}$ & & v926137 & & \\
\hline $\begin{array}{l}\text { Health and education } \\
\text { spending/taxes }\end{array}$ & Agree strongly & $\begin{array}{l}\text { Disagree } \\
\text { strongly }\end{array}$ & & & v940927 & \\
\hline $\begin{array}{l}\text { Increase welfare benefits } \\
\text { for mothers }\end{array}$ & Favor strongly & $\begin{array}{l}\text { Oppose } \\
\text { strongly }\end{array}$ & & & v940947 & \\
\hline Limit on welfare benefits & Oppose strongly & Favor strongly & & & v940949 & \\
\hline $\begin{array}{l}\text { Use federal surplus for } \\
\text { tax cuts }\end{array}$ & $\begin{array}{l}\text { Disapprove } \\
\text { strongly }\end{array}$ & $\begin{array}{l}\text { Approve } \\
\text { strongly }\end{array}$ & & & & p000690 \\
\hline
\end{tabular}


Table 5 Indicators of cultural policy preferences

\begin{tabular}{|c|c|c|c|c|c|c|}
\hline Item & Most liberal & $\begin{array}{l}\text { Most } \\
\text { conservative }\end{array}$ & 1990 & 1992 & 1994 & 2000 \\
\hline School prayer & $\begin{array}{l}\text { By law, should } \\
\text { not be allowed }\end{array}$ & $\begin{array}{l}\text { By law, should } \\
\text { have }\end{array}$ & v900467 & v925945 & v941020 & \\
\hline Flag burning & Should be legal & $\begin{array}{l}\text { Should be } \\
\text { against law }\end{array}$ & v900471 & & & \\
\hline Abortion & $\begin{array}{l}\text { By law, should be } \\
\text { choice }\end{array}$ & $\begin{array}{l}\text { By law, not } \\
\text { permitted }\end{array}$ & v900479 & v923732 & v941014 & p000694 \\
\hline $\begin{array}{l}\text { Parental abortion } \\
\text { consent }\end{array}$ & Oppose strongly & Favor strongly & v900481 & v923736 & & p000702 \\
\hline Federal abortion funding & Favor strongly & $\begin{array}{l}\text { Oppose } \\
\text { strongly }\end{array}$ & v900483 & v923738 & & \\
\hline $\begin{array}{l}\text { New lifestyles hurt } \\
\text { society }\end{array}$ & Disagree strongly & Agree strongly & v900500 & v926118 & v941029 & p001530 \\
\hline $\begin{array}{l}\text { Adjust moral views to } \\
\text { changing world }\end{array}$ & Agree strongly & $\begin{array}{l}\text { Disagree } \\
\text { strongly }\end{array}$ & v900501 & v926115 & v941030 & p001531 \\
\hline $\begin{array}{l}\text { Should emphasize } \\
\text { traditional family ties }\end{array}$ & Disagree strongly & Agree strongly & v900502 & v926117 & v941031 & p001532 \\
\hline $\begin{array}{l}\text { Should be tolerant of } \\
\text { different morals }\end{array}$ & Agree strongly & $\begin{array}{l}\text { Disagree } \\
\text { strongly }\end{array}$ & v900503 & v926116 & v941032 & p001533 \\
\hline $\begin{array}{l}\text { Notify husband before } \\
\text { abortion }\end{array}$ & Oppose strongly & Favor strongly & & v923740 & & \\
\hline Women's role in society & $\begin{array}{l}\text { Women and men } \\
\text { equal }\end{array}$ & $\begin{array}{l}\text { Women's place } \\
\text { is home }\end{array}$ & & v923801 & v940928 & \\
\hline $\begin{array}{l}\text { Supporters of } \\
\text { abortion-feeling } \\
\text { therm. }\end{array}$ & 100 & 0 & v900154 & & & \\
\hline $\begin{array}{l}\text { Women's movement- } \\
\text { feeling therm. }\end{array}$ & 100 & 0 & v900158 & v925324 & v940308 & p001318 \\
\hline $\begin{array}{l}\text { Opponents of } \\
\text { abortion-feeling } \\
\text { therm. }\end{array}$ & 0 & 100 & v900163 & & & \\
\hline $\begin{array}{l}\text { Gay men and lesbians- } \\
\text { feeling therm. }\end{array}$ & 100 & 0 & & v925335 & v940318 & p001321 \\
\hline $\begin{array}{l}\text { Christian } \\
\text { fundamentalists- } \\
\text { feeling therm. }\end{array}$ & 0 & 100 & & v925338 & v940315 & p001317 \\
\hline $\begin{array}{l}\text { Christian coalition- } \\
\text { feeling therm. }\end{array}$ & 0 & 100 & & & & p001322 \\
\hline $\begin{array}{l}\text { Protect gays against job } \\
\text { discrimination }\end{array}$ & Favor strongly & $\begin{array}{l}\text { Oppose } \\
\text { strongly }\end{array}$ & & v925924 & & p001481 \\
\hline $\begin{array}{l}\text { Allow gays in the armed } \\
\text { forces }\end{array}$ & $\begin{array}{l}\text { Feel strongly- } \\
\text { allowed }\end{array}$ & $\begin{array}{l}\text { Feel strongly- } \\
\text { not allowed }\end{array}$ & & v925926 & & p000727 \\
\hline Homosexual adoption & $\begin{array}{l}\text { Feel strongly- } \\
\text { allowed }\end{array}$ & $\begin{array}{l}\text { Feel strongly- } \\
\text { not allowed }\end{array}$ & & v925928 & & p000748 \\
\hline $\begin{array}{l}\text { Extramarital sex is } \\
\text { always wrong }\end{array}$ & Disagree strongly & Agree strongly & & v926119 & & \\
\hline
\end{tabular}


Table 5 continued

\begin{tabular}{|c|c|c|c|c|c|c|}
\hline Item & Most liberal & $\begin{array}{l}\text { Most } \\
\text { conservative }\end{array}$ & 1990 & 1992 & 1994 & 2000 \\
\hline $\begin{array}{l}\text { "Partial birth" abortion } \\
\text { ban }\end{array}$ & Oppose strongly & Favor strongly & & & & p000705 \\
\hline $\begin{array}{l}\text { Federal government gun } \\
\text { regulation }\end{array}$ & A lot stronger & A lot weaker & & & & p000731 \\
\hline
\end{tabular}

\footnotetext{
a This question was asked a second time in the post-election interview (p001403). Answers to both items were used for the cultural policy preference scale
}

Table 6 Rates of missing data on policy items

\begin{tabular}{lllllr}
\hline Scale & \multicolumn{5}{l}{ Percentage of items for which respondents had missing data } \\
\cline { 2 - 6 } & 0 & $1-25$ & $25-50$ & $50+$ & Total \\
\hline 1990 Economic Policy & 62 & 37 & 1 & 0 & 100 \\
1990 Cultural Policy & 83 & 14 & 2 & 1 & 100 \\
1992 Economic Policy & 52 & 46 & 2 & 0 & 100 \\
1992 Cultural Policy & 70 & 29 & 1 & 0 & 100 \\
1994 Economic Policy & 72 & 27 & 0 & 0 & 99 \\
1994 Cultural Policy & 84 & 15 & 1 & 0 & 100 \\
2000 Economic Policy & 44 & 56 & 1 & 0 & 101 \\
2000 Cultural Policy & 57 & 40 & 3 & 0 & 100 \\
\hline
\end{tabular}

Due to rounding, totals do not always add to 100

Table 7 Dimensionality of presidential evaluations

\begin{tabular}{llr}
\hline Year & \multicolumn{2}{l}{ Eigenvalues associated with } \\
\cline { 2 - 3 } & Factor 1 & Factor 2 \\
\hline 1990 & 3.19 & .27 \\
1991 & 2.04 & -.08 \\
1992 (Bush) & 3.40 & -.01 \\
1992 (Clinton) & 2.56 & -.05 \\
1994 & 2.96 & -.05 \\
1996 & 3.79 & -.02 \\
2000 & 2.06 & -.08 \\
2002 & 2.46 & -.05 \\
2004 & 2.64 & -.04
\end{tabular}

As described in the main text, a variety of indicators were used to create the measure of presidential evaluations. To test whether the indicators measured a single underlying latent variable, principal factor analysis was used. The cell entries report the eigenvalues associated with the first and second factors. In every case, it is clear that there is one dominant dimension of presidential evaluations 
Table 8 Parameter estimates of presidential approval

\begin{tabular}{|c|c|c|c|c|c|}
\hline & $\begin{array}{l}\text { H.W. Bush } \\
1990-1991\end{array}$ & $\begin{array}{ll}\text { H.W. Bush } & \text { Clinton } \\
1991-1992 & 1992-1994\end{array}$ & $\begin{array}{l}\text { Clinton } \\
\text { 1994-1996 }\end{array}$ & $\begin{array}{l}\text { W. Bush } \\
2000-2002\end{array}$ & $\begin{array}{l}\text { W. Bush } \\
\text { 2002-2004 }\end{array}$ \\
\hline Prior approval $\left(\hat{\beta}_{1}\right)$ & $\begin{array}{l}.531 * * \\
(.035)\end{array}$ & $\begin{array}{l}.437 * * \\
(.036)\end{array}$ & $\begin{array}{l}.520 * * \\
(.038)\end{array}$ & & $\begin{array}{l}.786^{* * *} \\
(.017)\end{array}$ \\
\hline Prior partisanship $\left(\hat{\beta}_{2}\right)$ & $\begin{array}{l}.172 * * \\
(.038)\end{array}$ & $\begin{array}{l}.250 * * \\
(.037)\end{array}$ & $\begin{array}{l}.184 * * \\
(.041)\end{array}$ & & $\begin{array}{l}.175^{* * *} \\
(.019)\end{array}$ \\
\hline $\begin{array}{l}\text { Prior economic attitudes } \\
\qquad\left(\hat{\beta}_{3}\right)\end{array}$ & $\begin{array}{l}.022 \\
(.035)\end{array}$ & $\begin{array}{l}.190 * * \\
(.035)\end{array}$ & $\begin{array}{l}.115 * * \\
(.037)\end{array}$ & & $\begin{array}{l}.004 \\
(.017)\end{array}$ \\
\hline Prior cultural attitudes $\left(\hat{\beta}_{4}\right)$ & $\begin{array}{l}.162 * * \\
(.033)\end{array}$ & $\begin{array}{l}.026 \\
(.033)\end{array}$ & $\begin{array}{l}.041 \\
(.031)\end{array}$ & & $\begin{array}{l}.070 * * \\
(.016)\end{array}$ \\
\hline $\begin{array}{l}\text { Joint policy effects: } \\
\text { prior economic } \\
+ \text { prior cultural } \\
\text { attitudes }\left(\hat{\beta}_{3}+\hat{\beta}_{4}\right)\end{array}$ & $\begin{array}{l}.184 * * \\
(.044)\end{array}$ & $\begin{array}{l}.216^{* *} \\
(.044)\end{array}$ & $\begin{array}{l}.157 * * \\
(.041)\end{array}$ & & $\begin{array}{l}.074 * * \\
(.021)\end{array}$ \\
\hline$N$ & 535 & 535 & 592 & & 744 \\
\hline$R^{2}$ & .47 & .48 & .56 & & .86 \\
\hline
\end{tabular}

All variables are standardized, and as a result the estimated intercepts are equivalent to zero and therefore not reported in the table. There are no entries for 1992-1994 and 2000-2002 because there is no measure of prior approval as Clinton and Bush were not yet president in 1992 and 2000, respectively. ** $p<.05$; $* p<.10$

\section{References}

Abramowitz, A. I. (1995). It's abortion, stupid: Policy voting in the 1992 presidential election. Journal of Politics, 57(1), 176-186.

Abramowitz, A. I. (2010). The disappearing center: Engaged citizens, polarization, and American democracy. New Haven, CT: Yale University Press.

Abramowitz, A. I., \& Saunders, K. L. (1998). Ideological realignment in the U.S. electorate. Journal of Politics, 60, 634-652.

Adams, G. D. (1997). Abortion: Evidence of an issue evolution. American Journal of Political Science, 41(3), 718-737.

Aldrich, J. H., Sullivan, J. L., \& Borgida, E. (1989). Foreign affairs and issue voting: Do presidential candidates 'Waltz before a blind audience'. American Political Science Review, 83(1), 123-141.

Ansolabehere, S., Rodden, J., \& Snyder, J. M., Jr. (2008). The strength of issues: Using multiple measures to gauge preference stability, ideological constraint, and issue voting. American Political Science Review, 102(2), 215-232.

Bafumi, J., \& Shapiro, R. Y. (2009). A new partisan voter. Journal of Politics, 71(1), 1-24.

Baldassarri, D., \& Gelman, A. (2008). Partisans without constraint: Political polarization and trends in American public opinion. American Journal of Sociology, 114(2), 408-446.

Bartels, L. M. (2002). Beyond the running tally: Partisan bias in political perceptions. Political Behavior, 24(2), 117-150.

Bartels, L. M. (2003). Democracy with attitudes. In M. E. MacKuen \& G. Rabinowitz (Eds.), Electoral democracy. Ann Arbor, MI: University of Michigan Press.

Bartels, L. M. (2010). Base appeal: The political attitudes and priorities of core partisans. Paper presented at the Annual meeting of the American Political Science Association.

Berelson, B. R., Lazarsfeld, P. F., \& McPhee, W. N. (1954). Voting: A study of opinion formation in a presidential campaign. Chicago: University of Chicago Press. 
Brewer, M. D. (2005). The rise of partisanship and the expansion of partisan conflict within the American electorate. Political Research Quarterly, 58, 219-230.

Brody, R. A. (1991). Assessing the president: The media, elite opinion, and public support. Stanford, CA: Stanford University Press.

Campbell, A., Converse, P. E., Miller, W. E., \& Stokes, D. E. (1960). The American voter. New York: John Wiley \& Sons.

Claassen, R. L., \& Highton, B. (2009). Policy polarization among party elites and the significance of political awareness in the mass public. Political Research Quarterly, 62, 538-551.

Converse, P. E. (1964). The nature of belief systems in mass publics. In D. E. Apter (Ed.), Ideology and discontent (pp. 206-261). New York, NY: Free Press.

DiMaggio, P., Evans, J., \& Bryson, B. (1996). Have American's social attitudes become more polarized. American Journal of Sociology, 102(3), 690-755.

Edwards, G. C., I. I. I., \& Tami, S. (1997). Who rallies? The anatomy of a rally event. Journal of Politics, 59(1), 200-212.

Erikson, R. S., MacKuen, M. B., \& Stimson, J. A. (2002). The macro polity. New York: Cambridge University Press.

Feldman, S. (1988). Structure and consistency in public opinion: The role of core beliefs and values. American Journal of Political Science, 32(2), 416-440.

Finkel, S. E. (1993). Reexamining the 'Minimal effects' model in recent presidential campaigns. Journal of Politics, 55(1), 1-21.

Finkel, S. E. (1995). Causal analysis with panel data. In M. S. Lewis-Beck (ed.). Beverly Hills, CA: Sage Publications.

Gaines, B. J., Kuklinski, J. H., Quirk, P. J., Peyton, B., \& Verkullen, J. (2007). Same facts, different interpretations: Partisan motivation and opinion on Iraq. Journal of Politics, 69(4), 957-974.

Gerber, A., \& Green, D. (1999). Misperceptions about perceptual bias. Annual Review of Political Science, 2, 189-210.

Gerber, A., \& Green, D. P. (1998). Rational learning and partisan attitudes. American Journal of Political Science, 42(3), 794-818.

Goren, P. (2002). Character weakness, partisan bias, and presidential evaluation. American Journal of Political Science, 46(3), 627-641.

Goren, P. (2005). Party identification and core political values. American Journal of Political Science, 49(4), 881-896.

Green, D. P., Palmquist, B., \& Schickler, E. (2002). Partisan hearts and minds. New Haven, CT: Yale University Press.

Gronke, P., \& Newman, B. (2003). FDR to Clinton, Mueller to?: A field essay on presidential approval. Political Research Quarterly, 56(4), 501-512.

Hibbs, D. A., Douglas Rivers, R., \& Vasilatos, N. (1982). On the demand for economic outcomes: Macroeconomic performance and mass political support in the United States, Great Britain, and Germany. Journal of Politics, 44(2), 426-462.

Huckfeldt, R., Johnson, P. E., \& Sprague, J. (2004). Political disagreement: The survival of diverse opinions within communication networks. New York: Cambridge University Press.

Kernell, S. (1978). Explaining presidential popularity: How ad hoc theorizing, misplaced emphasis, and insufficient care in measuring one's variables refuted common sense and led conventional wisdom down the path of anomalies. American Political Science Review, 72(2), 506-522.

Krosnick, J. A., \& Kinder, D. R. (1990). Altering the foundations of support for the president through priming. American Political Science Review, 84(2), 497-512.

Lasswell, H. D. (1936). Politics: Who gets what, when, how. New York: McGraw-Hill.

Layman, G. C., \& Carsey, T. (2002). Party polarization and 'Conflict extension' in the American electorate. American Journal of Political Science, 46, 786-802.

Lazarsfeld, P. F., Berelson, B., \& Gaudet, H. (1948). The people's choice: How the voter makes up his mind in a presidential campaign. New York: Columbia University Press.

Lodge, M., \& Taber, C. (2000). Three steps toward a theory of motivated political reasoning. In A. Lupia, M. D. McCubbins, \& S. L. Popkin (Eds.), Elements of reason. Cambridge: Cambridge University Press.

MacKuen, M. B. (1983). Political drama, economic conditions, and the dynamics of presidential popularity. American Journal of Political Science, 27(2), 165-192.

Markus, G. B. (1982). Political attitudes during an election year: A report on the 1980 NES panel study. American Political Science Review, 76, 538-560. 
Mayhew, D. R. (1974). Congress: The electoral connection. New Haven, CT: Yale University Press.

McCarty, N., Poole, K. T., \& Rosenthal, H. (1997). Income redistribution and the realignment of American politics. Washington, DC: American Enterprise Institute.

McCarty, N., Poole, K. T., \& Rosenthal, H. (2006). Polarized America: The dance of ideology and unequal riches. Cambridge: MIT Press.

Miller, W. E., \& Shanks, J. M. (1996). The new American voter. Cambridge: Harvard University Press.

Mutz, D. C. (2006). Hearing the other side: Deliberative versus participatory democracy. New York: Cambridge University Press.

Newman, B. (2002). Bill Clinton's approval ratings: The more things change, the more they stay the same. Political Research Quarterly, 55(4), 781-804.

Newman, B. (2003). Integrity and presidential approval, 1980-2000. Public Opinion Quarterly, 67, 335-367.

Ostrom, C. W., Jr., \& Simon, D. M. (1985). Promise and performance: A dynamic model of presidential popularity. American Political Science Review, 79(2), 334-358.

Peffley, M., Langley, R. E., \& Goidel, R. K. (1995). Public responses to the presidential use of military force: A panel analysis. Political Behavior, 17(3), 307-337.

Prior, M. (2007). Post-broadcast democracy: How media choice increases inequality in political involvement and polarizes elections. New York, NY: Cambridge University Press.

Rahn, W. (1993). The role of partisan stereotypes in information processing about political candidates. American Journal of Political Science, 37(2), 472-496.

Stimson, J. A. (2004). Tides of consent: How public opinion shapes American politics. New York, NY: Cambridge University Press.

Stokes, D. E. (1963). Spatial models of party competition. American Political Science Review, 57(2), 368-377.

Stokes, D. E. (1966). Some dynamic elements of contests for the presidency. American Political Science Review, 60(1), 19-28.

Stroud, N. J. (2008). Media use and political predispositions: Revisiting the concept of selective exposure. Political Behavior, 3(3), 341-366.

Taber, C. S., \& Lodge, M. (2006). Motivated skepticism in the evaluation of political beliefs. American Journal of Political Science, 50(3), 755-769.

Taber, C. S., Lodge, M., \& Glathar, J. (2001). The motivated construction of political judgments. In J. H. Kuklinski (Ed.), Citizens, politics: Perspectives from political psychology. New York: Cambridge University Press. 